\author{
Review Article \\ www.ijrap.net
}

\title{
A REVIEW ON DIFFERENT TREATMENT MODALITIES IN FISTULA IN ANO: AN AYURVEDIC AND MODERN ASPECT
}

Vaikhari A. Dhurve ${ }^{1}$, Kiran S. Deshbhratar ${ }^{2 *}$, M.N. Suryawanshi ${ }^{3}$

${ }^{1}$ Junior research fellow, Regional Ayurveda Research Institute for Mother and Child Health, Nagpur, India

${ }^{2}$ Research Officer (Ayurveda), Regional Ayurveda Research Institute for Mother and Child Health, Nagpur, India

${ }^{3}$ Assistant. Director In-charge, Regional Ayurveda Research Institute for Mother and Child Health, Nagpur, India

Received on: 20/01/17 Revised on: 11/02/17 Accepted on: 02/03/17

*Corresponding author
E-mail: kalekiran2004@yahoo.co.in

DOI: $10.7897 / 2277-4343.08251$

\section{ABSTRACT}

In a field of surgery, patients faced most frequent problem is fistula in ano. It is notorious disease and having more recurrence rate. In Ayurveda, it was mentioned as mahagad. Fistula originates from anal glands, which are located between the internal and external anal sphincter and drain into anal canal. If the outlet of these glands becomes blocked, abscess can form which can eventually extend to skin surface. The tract formed by this process is fistula. There are many options available for treatment of fistula in ano but due to lack of knowledge patients undergo wrong treatment and worsen disease so focus is drawn on various treatment described in Ayurvedic Samhita as well as modern science to came certain conclusion for making treatment of specific condition of these diseases.

Keywords: Fistula in ano, Ayurvedic treatment, Modern treatment.

\section{INTRODUCTION}

Due to change in life style, anorectal diseases like piles, fistula in ano, fissure are common in human being. Among them fistula in ano most common. Bhagandara (fistula in ano) Sushruta has described Bhagandara disease like disease in which there is daran (deformity) of bhag (pubis), gud (anus) and basti (bladder). ${ }^{1}$ Vagbhat says in bhagandara there is pustule or swelling formation near anus within periphery of two fingers. ${ }^{2}$

A fistula is an abnormal communication between anal canal and rectum with exterior (perennial skin) even though multiple openings are seen in perennial skin the internal opening is always single. ${ }^{3}$ most fistulas arise because of crypto glandular infection with resultant perennial abscess. Abscess represent acute inflammatory event, whereas fistula is representative of chronic process.

Treatment of fistula in ano remains challenging. ${ }^{4}$ No definitive medical therapy is available for this condition, though long term antibiotic prophylaxis and inflexible may have role in recurrent fistulas.

\section{Etiopathogenesis}

Occurs due to persistent anal gland infection which results in anorectal abscess which rupture inside as well as outside resulting in a fistula.

Patients with pulmonary TB have got $1-2 \%$ chances of developing multiple fistulas in ano.

Western countries, ulcerative colitis, Crohn's disease responsible for multiple fistulas in ano.

Colloid CA of rectum can present as multiple fistula in ano. ${ }^{4}$

\section{Classification}

A] Standard classification

1. Subcutaneous $(5 \%)$
2. Submucose $(5 \%)$

3. Low anal $(75 \%)$

4. High anal $(8 \%)$

5. Perirectal

\section{B] Parks classification}

1. Intersphincteric $(64 \%)$

2. Transphincteric $(30 \%)$

3. Supralevater ${ }^{5}$

Epidemiology-

True prevalence is unknown. The incidence of fistula in ano developing from abscess ranges from 26 to $38 \%$. One study showed that prevalence of fistula in ano is 8.6 cases per1, 00,000 populations. ${ }^{6}$

\section{Clinical Features}

- Persistent seropurulent discharge, keeps part always wet.

- Previous history of anal gland infection with recurrent abscess.

- External opening can be single or multiple with pouting granulation tissue, may discharge blood. ${ }^{7}$

- Goods all's rule- A fistula with an external opening in anterior half of anus within $3.75 \mathrm{~cm}$ tract to be direct type and in posterior half, indirect type, curved or horse-shoe type. $^{8}$

\section{Physical Examination}

Observe entire perineum looking for external fistula opening that appear as sinus or elevation of granulation tissue, spontaneous discharge of pus or blood via external opening.

$\mathbf{P} / \mathbf{R}$ digital examination- reveal fibrous tract, lateral or posterior indurations suggest deep post anal or ischiorectal extension. 
Anoscopy / proctoscopy- To identify internal opening.

Probing examination- In a probing a malleable medium sized probe is used. Probe is inserted into external opening and forefinger of other hand is inserted into anal canal feel the tip of probe into anal canal. It should be done careful not to create an artificial opening by force.

Sigmoidoscopy- A thin, flexible tube or rigid scope with lighted camera inside the tip is used to view the rectum and sigmoid colon.

Lower gastrointestinal series- In this procedure a barium sulfate radio contrast agent enema given through rectum then radiographs are taken. Two types of lower GI series are-a single -contrast lower GI series which uses only barium. A double contrast lower GI series, which uses both barium and air for a clearer view of large intestine.

\section{Fistulography}

Injection of contrast via the internal opening which is followed by anterior, posterior, lateral and oblique radiographic images to outline the course of fistula tract. Fistulography is generally reserved for cases in which there is concern about a fistulous connection between rectum and adjacent organ such as bladder.

\section{End anal or End rectal ultrasonography}

It involves the passage of a 7 to $10 \mathrm{MHz}$ ultrasound transducer into anal canal to help definite the muscular anatomy and thereby help intersphincteric from transphincteric lesion.

\section{MRI}

Finding on MRI show $80-90 \%$ concordance with operative findings when a primary tract course and secondary extension are observed. MRI becoming study of choice for evaluation of complex fistulas and recurrent fistulas.

\section{CT}

CT is more helpful in the setting of per rectal inflammatory disease then in setting of small fistulas because it is better for delineating fluid pockets that requires drainage than for delineating small fistulas. CT required administration of oral and rectal contrast.

\section{Anal Manometry}

Anal manometry is rarely used in the evaluation of patients with fistula in ano. However, pressure evaluation of the sphincter mechanism is helpful in certain patients for operative planning, including following

- Patients in when decreased tone is observed during preoperative evaluation

- Patients with history of previous fistulotomy

- Patients with history of obstetrical trauma

- Patients with a high transphincteric or suprasphincteric fistula.

If decrease in pressure is found, surgical division of any portion of sphincter mechanism should be avoided. ${ }^{9}$

\section{MODES OF TREATMENT}

\section{Ayurvedic treatment}

According to Sushruta, the disease admits of being divided into five different group of which the two known as sambukavarta and shalyaj (traumatic) should be regarded as incurable and rest as extremely difficult to cure.

\section{General treatment}

Eleven kinds of remedial measures commencing with aptarpan up to purgatives should be employed as long as any fistula ulcer would remain in an in suppurated stage. ${ }^{10}$

According to Sushruta an experience surgeon should know that langalaka, ardhalangalak, sarvatobhadraka and gotirthaka from of incision should be different shape of incision in a case of a many-mouthed shataponaka. The ulcer should first be searched with probe or director and after an operation; an alkali should be applied to it. A plaster of clarified butter and pasted sesames should then be applied to it and ulcer duly bandaged.

In case of parisravi, where there is bleeding and secretion from the ulcer, the sinus and cavities of pus should be first removed and then cauterized with an alkali. When ulcer found softened, free from pain and secretion should be searched with a probe and should be cut open and cauterized with fire or alkali incision should be made in shape of khajura-patra, ardhachandra, chandrachakra, suchi-mukha. In case of agantuka bhagandara should be carefully cut open and cauterized. A/c to rules laid down with red hot jambvostha or red hot director. In case of tridoshaj bhagandara due to concerted action of three doshas should be treated without holding out any hope of recovery to the patient ${ }^{11}$

\section{Ksharsutra ligation}

From the reference of Chakradatta, Rsatarangini, decided to give the kshara sutra therapy a new life. First designed the snuhi kshara sutra, tried out this experimentally in animals and then small group of patients and found remarkable results. Later on, Dr. P J Deshapande, Dr. S N Pathak, Dr. K R Sharma and others, adopted this in large number of patients and established the treatment as an affective, ambulatory and safer alternative treatment for patients with fistula in ano.

Ksharsutra is a medicated alkaline thread prepared by smearing seven times in the latex of snuhi, eleven times apamarg kshara and three times haridra. Surgical linen Thread no 20 used then thread kept inside specially designed cabinet. Thread has cutting, curating, cleaning and healing properties. Number of drugs like apamarg kshar, khadali kshar, arka kshar, nimb kshar, snuhi kshar, udumbar kshar, papaya kshar are used ${ }^{12}$.

\section{Modern treatment}

Anal fistulas are almost never found to heal spontaneously. Most commonly followed mode of treatment is laying open entire tract of removing fibrous tissue and pyogenic membrane. In certain cases, a silk Seton is passed through parts of the tract

\section{Fistulotomy}

Fistulotomy is to open the fistula tract and allow healing from baser by secondary intension. Excision of tract and surrounding tissue, division of tract and drainage of tract by set on. Depending of depth of wound daily dressing require.

\section{Advancement rectal flap}

In this procedure, internal fistulous opening is identified. A flap of mucosal tissue cut around opening, flap lifted and removed internal opening. Cutting the end of flap, flap is placed down over internal opening and suture in place. External opening is cleaned and suture.

\section{Fibrin glue}

Fibrin glue was instilled into internal fistula tract by an external opening so its tip was seen emerging from internal opening into anal canal. Tube introduced in the bottom of fistula and continuously withdrawn during injection so fistula tract filled 
with fibrin glue, finally suture at internal opening was tied completing the procedure.

Fistula plug management

A plug of collagen protein may also be used to seal and close the fistula tract. ${ }^{13}$

\section{VAAFT}

Video assisted anal fistula treatment uses a specialized kit to remove fistula using an instrument that has a video camera on the end of it. This is so the surgeon can see the fistula while they treat it.

\section{LIFT Procedure}

A new technique for treating a complex fistula is called ligation of intersphincteric fistula track procedure. This involves tying your fistula off within your sphincter muscle then implant of a piece of biological mesh to stop the fistula reforming.

\section{Seton placement}

A Seton can be placed alone, combined with fistulotomy or in a staged fashion. This technique is useful in complex fistulas (high intersphincteric, suprasphincteric, extrasphincteric), recurrent fistulas. Patients with chronic disease or immunosuppresed. ${ }^{14}$

\section{Complication}

Incontinence, urinary retention, bleeding, thrombosed hemorrhoids, anal stenosis, delaying wound healing. ${ }^{14}$

\section{CONCLUSION}

The prevalence of fistula in ano is increasing day by day. Treatment of fistula is remains challenging. There are different modalities of treatment in Ayurveda and modern medicine. It needs to be diagnosed the type of fistula and early and appropriate treatment so there is no recurrence of fistula in ano.

\section{REFERENCES}

1. Kaviraj Ambikadutta Shastri. Susrutasamhita nidansthan 4/4. Chaukhamba publication edition 2010.p.317

2. Kaviraj Abhidevraj Gupt. Astang Sangraha, nidansthan 8/30, Chaukhamba prakashan Varanasi 2009, p.339

3. K.Rajgopal Shenoy. Manipal Manual of Surgery, 2000 p. 462

4. K.Rajgopal Shenoy. Manipal Manual of Surgery, 2000 p.463

5. Parks AG, Gordon PH, Hard Castle JD, A Classification of fistula in ano. Br J.Surg. 1976Jan 63(1):1-12[Medline]

6. Emedicine.medscape.com article/190234/overview on fistula in ano

7. K.Rajgopal Shenoy. Manipal Manual of Surgery, 2000 p.463

8. Emedicine.medscape.com/article on overview on fistula in ano

9. Kaviraj ambikadutta Shastri. Susrutasamhinta chikistasthan 8/4. Chaukhamba Prakashan Varanasi 2010.p 57

10. Kaviraj ambikadutta Shastri. Susrut samhinta chikistasthan 8/8. Chaukhamba Prakashan Varanasi 2010.p 33

11. www.nhp.gov.in/ksharsutra therapy

12. colorectal.surgery.ucsf.edu/co

13. www.bupa.co.uk/health information -Anal surgery

14. Emedicine.medscape.com/article/190234/overview fistula in ano

\section{Cite this article as:}

Vaikhari A. Dhurve et al. A review on different treatment modalities in fistula in ano: An Ayurvedic and modern aspect. Int. J. Res. Ayurveda Pharm. 2017;8(2):1-3 http://dx. doi.org/10.7897/2277-4343.08251

Disclaimer: IJRAP is solely owned by Moksha Publishing House - A non-profit publishing house, dedicated to publish quality research, while every effort has been taken to verify the accuracy of the content published in our Journal. IJRAP cannot accept any responsibility or liability for the site content and articles published. The views expressed in articles by our contributing authors are not necessarily those of IJRAP editor or editorial board members. 